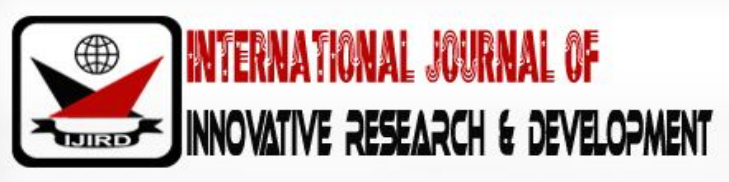

ISSN 2278 - 0211 (Online)

\section{Exploring Concerns Raised by University-Based Supervisors of Post Graduate Diploma in Education (PGDE) Students on Teaching Practice (TP)}

\author{
Wonderful Dzimiri \\ Senior lecture, Midlands State University, Zimbabwe \\ Mercy Kurebwa, D \\ Professor, Zimbabwe Open University, Zimbabwe
}

\begin{abstract}
:
Teaching practice (TP) is a fundamental component of teacher education and preparation. The importance of TP lies in that it brings reality to theoretical underpinnings of the practice of education. Concerns have been raised by university-based lecturers arising from supervision of Post-graduate Diploma in Education (PGDE) student's on TP. We argue that knowledge of such concerns are pertinent bases for continuous professional development of teacher education lecturers as a learning community aimed at improving the quality of student teacher development. This study sought to analyze concerns observed by university-based supervisors of PGDE students on teaching practice. Undergirded by an interpretive framework, this study employed a case study design involving university-based supervisors from two Zimbabwean universities offering the PGDE programme. Purposive sampling assisted in identification of twenty information-rich participants involved in the supervision of PGDE students on TP. Data generation techniques included in-depth interviews and document analysis. Data were analyzed using thematic analysis where themes emerged from the data. Findings revealed that most students generally did not prepare for their teaching in advance, lacked confidence, and shifted into a panic mode upon arrival of University-based supervisors. Others failed to reflect the scientific structure of a lesson in their lesson plan and lesson delivery. Others taught without media, and if they had these were poorly designed. Marking of learners written work was not communicative, and at times not done. Evaluations were neither responsive to set objectives nor followed up in later planning. The study recommends that student teachers be given practice in detailed lesson planning, media selection and development, and that each student needs be provided with micro teaching experience prior to TP, coupled with clinical supervision at the onset of TP. Furthermore, there is need for a connectedness between school-based and university-based supervisors to standardize expectations.
\end{abstract}

Keywords: Teacher development, student teacher, PGDE, teaching practice, teaching practice supervision, lecturers' concerns

\section{Introduction}

Teaching practice (TP) is an indispensable component of any teacher education or preparation programme. As Furlong et al. (1988) observe, TP provides beginning teachers or student teachers with the opportunity to be socialised into the profession. This socialisation process enables student teachers or teacher trainees to acquire and develop purposeful scientific experiences that include knowledge and skills needed to perform their future roles as qualified teachers (Mostafa, 2005, in Wambugu et al., 2013). Thus, TP situates itself in a key position in teacher education programmes. As a culminating experience in any teacher preparation programme, TP provides the teacher educator with some prediction of the future success of a teacher. As Farauta and Omuche (2013) argue, TP then becomes a yardstick or factor determining the quality of a teacher education programme. In other words, a teacher education programme would be incomplete without the TP component because TP brings to life the theoretical underpinnings of the practice of education at a given level. Arguably, the TP component takes the student from the college world of theory into the practical field of classroom practice. It is also the time when the student teacher gets to work with experienced, qualified teachers, variably known as school-based mentors, which is a crucial step in one's learning to be an effective teacher(Wilson et al., 2001). 
In light of the above, the quality of student teacher preparation for teaching practice should be informed by the strengths and weaknesses that supervisors identify when they observe or assess students on TP. This study focused on concerns that university-based supervisors or lecturers experience when they supervise students on TP.

To place this paper into a shared perspective, we need to know, and share the same view of what teaching practice (TP) means.TP is a form of field work, practicum, or on-the job experience, now termed 'work-related learning' availed to the student teacher as part of teacher training or teacher preparation programme. As Aljasah and Altamar (2004) explain, TP is that part of the teacher education programme whereby a student goes out to the field to experience the classroom situations and take charge of these, as well as responsibility for each situation. This is where the student teacher builds confidence, puts theory into practice, learns practically about student behaviour, tests and demonstrates his/ her level of subject content mastery, receives constructive criticism from both university/ college-based and school-based supervisors, discovershis/ her strong and weak points, and learns "pedagogical values to which a professionally competent teacher adheres to" (Wambugu \& Ng'enu, 2013, p. 170).

In their practical guide to teaching and learning, Gultig andTielau (2012) emphasise the crucial place of teaching and learning resources, commonly referred to as teaching-learning media, in successful lesson delivery. Traditionally, we would include media such as overhead projectors, charts, maps, work cards/ worksheets, slide machines, et cetera, forgetting that chalkboards, the teacher's voice, our learners and their lives, popular media (print and electronic), and the local environment(physical buildings and places, human, waste products) all constitute teaching and learning resources. Therefore, to add value to the lesson through use of teaching and learning resources requires careful thought and planning in the framework of thoughtfully formulated lesson objectives. The benefits of teaching-learning resources in a lesson include:

- giving learners real-life and relevant experiences that assist them to understand new ideas and concepts;

- assisting learners to discover new ideas for themselves;

- affording learners opportunities to develop new skills;

- creating interest in learners and making learning more fun; and

- providing learners with the opportunity to be practically involved in, and taking responsibility for, their own learning (Gultig \& Tielau, 2012, p. 354).

Gultig and Tielau (2012) further note that most teachers did not want to be watched teaching, which is an indication of "lack of collegiality, and of peer observation and mentoring" (p. 485) - factors contributing to practice among teachers. Arguably, student teachers on TP must have opportunity to watch qualified teachers to whom they are attached (school-based mentors) teach as a way to learn together and develop teaching competence in both mentor and mentee. A collegial atmosphere where the student teacher and mentor share ideas without fear of criticism improves the student's teaching practice. This scenario is akin to Senge's (2006) discipline of team learning.

Furthermore, Gultig and Tielau (2012) advocate for purpose-driven planning informed by various theories of learning and development. The lesson steps must be well thought-out with purposeful approaches where whole class, group work, teaching and learning resources, and assessment are reflectively selected towards successful lesson outcomes.

\section{Theoretical Framew ork}

Framing the teaching practice phenomenon and its context in this study, and also defining its importance, is the Capital Theory wherein the social capital relates to external and internal ties that exist among people (social actors) who have a relationship and resources they bring into the partnership with the aim to secure benefits (Adler \& Kwon, 2002). Arguably, while at face value it might appear that the student teacher is the ultimate beneficiary, yet internal relations imply that TP should benefit the supervisor by informing his/her teacher preparation generally, and in particular the preparation of students for teaching practice. Thus, both lecturer and the student teacher bring in resources into the TP knowledge capital that they share and construct as a result of the supervision encounter. While the external ties relate to bridging ways, the focus lies in capital as a resource inherent in the social network (with school-based mentors, for example) where the supervisor as the focal actor cascades his/ her dream (expectation) that the three parties weave together for the success of the common cause or purpose (Khuzwayo, 2016). Thus from the TP experience, the encounter feeds into the development of student teacher preparation for TP, as well as professional development of the student teacher in practice through feedback.

On the other hand, Caldwell and Spinks (2008) see intellectual capital as concerning the knowledge and skills of people working, say in a school, which can be taken as organised knowledge whose spill-over benefits are its utilisation in wealth production (Hargreaves, 2001). In the context of this study, it is knowledge that university based supervisors and student teachers produce in context (TP) as partners in teacher development, that they bring to create, share and transfer among themselves so as to realise long-lasting partnership. At the heart of this framework also is the importance of the study whereby the supervisor's supervision experience (out of the social capital) in terms of concerns noted becomes a source of intellectual capital that can be brought into reflection to inform future efforts towards programmes aimed at preparing students for TP on one hand, and teacher development programmes on the other. Thus, this study adds to the huge body of existing literature by bringing in experiences that are Zimbabwe-specific, and also specific to university run teacher education programmes. 


\section{Methodology}

\subsection{The Navigation Tool CASE}

As a lens through which to view the concerns of university-based supervisors of PGDE students on teaching practice, we chose interpretive framework to undergird this study. As Taylor and Madina (2010) cited in Khuzwayo (2016) believe, the aim was to understand the culturally different 'other' (the supervisor) by learning to 'stand in their shoes' given that a lot of studies have explored TP concerns from the perspective of students. From this perspective, we felt that we could look through the university-based supervisor's'eye/ s' and have 'a feel of their worries or concerns,' thus learning where teacher preparation should focus on for improvement. Interpretive researchers seek to understand "the world of human experience" (Cohen et al., 2005, p.36), implying that reality is socially constructed as supervisors interact with student teachers, and the concerns they raise on TP resulting from their experience with TP supervision. Arguably, we employed a qualitative approach since our aim was to learn, discover and understand the experiences, perspectives and thoughts (Hiatt, 1986 in Harwell, 2012) of universitybased supervisors on PGDE students on teaching practice. We employed a qualitative case study design that is particularistic or characteristic since our focus was on a particular programme (Litchman, 2006; Babbie, 2007), wherein we purposively selected two state universities offering post graduate diploma in education programmes through Open Distance Learning (ODL) from which twenty lecturers involved in PGDE TP supervision were purposively selected. We collected data using indepth interviews and content analysis of supervision reports and sample artefacts, which built in triangulation to enhance trustworthiness of findings. In line with interpretive research, data were collected until saturation point when no new data emerged (Dzimiri, 2004). Data were analysed using thematic analysis in line with qualitative approach, where themes emerged from the data where in recurring responses that patterned were organised around the themes.

\section{Findings}

\subsection{Learning from the Research Excursion}

This study explored the concerns raised by university-based supervisors on PGDE students' teaching practice. Findings were organised around themes where under we placed responses that patterned.

\subsection{Absence or Incomplete Documentation}

The first theme that emerged was absence or incomplete preparation documents. Participants indicated that they found some students with no schemes of work two or three weeks into their TP period. One participant had a sad story:

See, I got to the school office and the school head summoned the student and handed me over. We went to the teaching venue and the student started teaching while I also began perusing the file and other documents. I then discovered that he had no scheme of work, and this was a form 4 class he was teaching. Worse still, there was no single detailed lesson plan (DLP). On asking, he had no single excuse or explanation. Because we had driven over $500 \mathrm{~km}$ to this school, I got very disappointed and angry, if I may say.

Also common in responses was lack of lesson plans, or mere sketches of notes that lacked detail enough to be meaningful to a second party. As one participant indicated:

Some of our students have the audacity to come to work, teach a class with no lesson planning done. In some instances, you would think that the person scribbled on sight of the university vehicle entering the school parking lot.

Another participant questioned the seriousness of the students given how badly they want the qualification, and the monies they pay in tuition fees. Similar observations were made in some supervision reports perused where some students were failed on the basis of the absence of, or uninformative detailed lesson plans (DLPs). As said by one participant, a DLP that lacks requisite detail can never be a DLP. Going by Gultik and Tielau's (2012) guidelines, a lesson taught without prior preparation is no lesson. Lesson planning is indispensable and is something that calls for thoughtful, reflective decisions that are informed or underpinned by theory.

\subsection{Poorly Stated Objectives}

Data also pointed to another key concern raised by participants relating to some students having problems with framing and stating smart, measurable, achievable objectives. This concern embodied stating lower order objectives and trivialising higher order objectives, and illogical sequencing of objectives (starting with higher order to lower order). As noted by one participant, "... the principle of simple to complex still applies to listing of objectives, and the content and lesson development must also evidence that." This concern was tied to the next theme below.

In fact, poorly stated objectives reflect poor planning skills as well as failure to apply theory to practice because all learning proceeds from the familiar to the unfamiliar with necessary connections between, and building on from known to unknown (Gutlik and Tielau, 2012; Wambugu \& Ng'neu, 2013). 


\subsection{Poorly Structured Lessons}

Evidence from interviews and supervision reports indicated that some students delivered lessons that lacked scientific or logical structure. One participant retorted,

How can a teacher start off the lesson with group work, or worse still move to group work after the lesson introduction? The logic is something must happen to prepare learners for group work. Similarly, you have scenes were learners start individual work after one step of whole class teaching.

Explaining further, the same participant declared that: "The ideal is to expect movement from introduction, whole class, group work and feedback, then learners can be ready for individual work."There was general agreement in evidence from a number of participants that a poorly structured lesson plan and lesson delivery translated into a poor lesson that fails to realise pre-set lesson objectives. A lesson carefully and thoughtfully planned must show local sequencing of the dynamics and that learners need to be prepared for each activity - class discussion or teacher exposition, group work and feedback - and that each activity must be well resourced (Gutlik \& Tielau, 2012). As Gutlik and Tielau (2012) emphasise, each step of the lesson must be resourced so that learning becomes fun for the learners.

\subsection{Poor Lesson Delivery}

Another important common concern that emerged from data was that of poor lesson delivery, which had a number of components or issues. The first related to structuring or sequencing of activities. One participant recounted how a student teacher had the same activity in the introduction come again as the first step in the lesson development. The participant indicated (shaking his head in disbelief), "Oh this student, he had the same introductory activity repeated as step one in the lesson development. As if that was not enough, the whole lesson was just 'teacher talk' or lecturing with no learner involvement except in the 'question and answer' that punctuated the' teacher-talk'." Asked whether that had been indication of panic on the part of the student, the participant claimed that the "DLP itself was just ina similar mess," thus confirming an earlier view that a poorly crafted DLP resulted in a poor lesson delivery. Asked to give her view, one participant indicated that student teachers needed to know that, "a lesson must move from simple to complex so that knowledge is presented, and proceeds in a developmental manner infused with the interaction dynamics that ensure student involvement ... haah objectives then become achievable."If lesson delivery is linked to lesson planning, then it means the point of student teachers' issues lay in the planning or preparation, which must be thoughtful, purposeful and informed by theory.

Furthermore, a common observation by participants also was inadequate time allocation for group work. In the words of one participant, "... giving three minutes to group work is taking group work as a norm or ritual fulfilment of an assessment criterion without thoughtful or purposeful preparation. Still tied to group work, another recurring observation was students' lack of purposeful consideration of the place of group work in a lesson, and its value. As one participant elaborated,

You see a student teacher giving the same task to five or six groups in the class and later having each of the five groups report back to the whole class, at times the same answer. No, no, no! The idea is to give five or six different tasks to these groups so they report to the rest. This way there is collaborative and cooperative learning. Besides, the class covers five or so tasks in the time of one. If tasks are the same for all groups and the first group to report responds correctly, what is the logic of continuing to have the second and subsequent groups proceed to report back on the same task to the whole class? See, such group work is as good as whole class teaching.

The above observation reveals that students or cases referred to lacked knowledge of the theoretical bases that inform the use of group work in teaching and learning whereby, as Gutlik and Tielau (2012), planning must be informed by theory. Thus group work must enhance both collaborative and cooperative learning.

\subsection{Poorly Planned, Prepared, or No Media at All}

Evidence pointed to supervisors' observations where student teachers executed lessons with either no media at all, or had poorly prepared media. On teaching without media, one participant lamented, "How can a student deliver a lesson with no media at all knowing that it's one of key criteria with mark allocation for it... I can't believe it. It is really not the mark that is important, but the whole purpose or role of media in teaching and learning. It emerged also that even where the media were specified in the DLP, these were absent in the lesson delivery. Where media were available or used in lesson delivery, some participants indicated their experience with charts that had very small print not visible from the different ends of the classroom, or just had clumsy script carelessly written and not attractive. Carefully planned and prepared media or lesson resources must create the requisite motivation and activity for learners to demonstrate attainment of intended lesson objectives. Furthermore, preparation of group work includes even the timing and how the teacher moves around resourcing verbally the different groups. Arguably, absence of teaching learning resources or media denies learners a wide range of benefits (Gutlik and Tielau, 2012).

\subsection{Lack of School-Based Support}

A number of factors emerged from the data to constitute lack of school-based support as a theme. First was absence of consistent school-based assessment reports where either the mentor, head of department, deputy head or school head writes an assessment report as evidence of school-based supervision of lesson delivery and attendant documents. As one participant lamented: 
You get to a school on say a third university assessment visit and the student has not a single school-based assessment report. Then when three or four assessment reports suddenly emerge two weeks or just days to end of work related learning or teaching practice period, one wonders as to the authenticity, purposefulness of such assessments. We need school-based assessment reports that are evenly distributedto show consistent supervision by the school personnel to facilitate gradual professional development of the student.

The second factor related to what participants termed 'ritual mentoring' where quality and consistency of record keeping and maintenance were not checked. Lack of consistency manifesting in irregular lesson planning, individual progress entries, and other records not up to date, progress record entries undated and/ or content of work recorded not indicated. For one participant, "Such meaningless progress records render themselves useless. They don't tell me much about the learner's progress and neither can they inform administrative or pedagogical decisions." Assessment records are indispensable given the purposes of recording students' progress as Gutlik and Tielau (2012) note, among which is reporting.

A third concern pointed to failure by school-based mentors to act as models. Participants raised as concern, cases where mentors did not provide model lesson deliveries that student teachers could observe and both engage in a post conference. As one participant argued, "The mentor must contribute to professional development of the student through checking documentation and modelling teaching. This is important." Another participant retorted,

Our major challenge is that some of the mentors appear out of touch with current trends in terms of university requirements and teaching methods. Some don't even bother to read the Teaching Practice Guide in student teachers' teaching practice files to familiarise with university expectations and criteria.

The idea behind attaching the student to a qualified teacher ormentor should provide a platform for the student teacher to learn to be effective (Wilson et al., 2001). This is akin to Senge's (2006) Team Learning discipline wherein one has to be watched and learn together in practice. The student must watch the mentor teach, and the mentor in turn watch the student teach (modelling); a scenario that allows both to learn and build into their practice the shared knowledge or professional capital (Cadwell \& Spinks, 2008) with the ultimate goal of improving practice. Without the mentor modelling lesson delivery, both student teacher and mentor are denied the benefits that accrue from the mentor-mentee partnership, relationship and resources so vital in development of professional capital as viewed by Adler \& Kwon (2002).

\section{Conclusion}

\subsection{Reflecting on the Excursion}

The concerns that supervisors (lecturers) amount to lack of thorough preparation of student teachers for teaching practice (TP), from documentation to actual teaching. There is also evidence of a disconnect between host schools and mentors, and the absence of collaboration between the two parties in a connected relationship that should result in making student teachers effective practitioners. Viewing the above dynamics through the Capital Theory, it is apparent that the social actors (university supervisor, student teacher and mentor) were not bringing into their tripartite relationship or partnership the necessary resources (i.e. skills and knowledge or intellectual capital) needed for success of the common cause, which is effective student teacher practitioner.

The observations or concerns that emerged from findings are knowledge capital that university based supervisors can employ to make their practice reflective and developmental.

\section{Recommendations}

\subsection{Where To From Here?}

Based on the findings, certain pointers to the way forward emerge that can assist to make the student teachers' TP experience enriching:

- Prior to going out on TP, student teachers need to be prepared in areas of documentation, foundations and practice of lesson planning, group work, resource/ media planning and preparation, lesson delivery, progress records, et cetera. Such preparation should include model artifacts, realia or samples that students can frame theirs based on.

- Every student teacher must be exposed to micro teaching under observation -making sure each one takes part, followed by constructive feedback discussion.

- University supervisors should mount workshops to appraise host school leaders and qualified teachers or mentors on expectations and standards;

- University supervisors should continually reflect on their experiences and use observations made to inform their preparation programmes or curricular for continuous improvement.

- Clinical supervision by university supervisors at the onset of students' TP must be afforded each student, followed by feedback conferences. Such supervision should bring also school-based mentors into the conference session, which should also render opportunity to emphasise to mentors university expectations and their mentor role. 


\section{References}

i. Adler, P. S., \& Kwon, S. W. (2002). Social Capital: Prospects for a New Concept. The Academy of Management Review, 27, 146-154.

ii. Babbie, E. (2007). The practice of social research. Belmont: Thompson Wadsworth.

iii. Caldwell, B. J., \& Spinks, J. M. (2008). Raising the stakes: From improvement to transformation in the reform of schools. London: Routledge.

iv. Cohen, L., Manion, L., \& Morrison, K. (2005). Research Methods in Education. (5thed.)

London: Routledge.

v. Dzimiri, W. (2004). A qualitative case study of the implementation of school governance reform in Zimbabwe. (Published dissertation).

vi. Farauta, K.G. (2013). Assessment Attitude of Education Students towards Teaching Practice in Nasarawa State University Keffi, Nigeria.Journal of Education and Practice. Vol. 4, (13), pp 181-188.

vii. Gultig, J. \& Stielau, J. (eds.) (2012). Getting practical: A guide to teaching and learning. (3rd ed.) Cape Town: Oxford University Press.

viii. Furlong, V.J., Hurst, P. U., and Pocklington, K. (1988). Initial teacher training and the role of the school. Philadelphia: Open University Press.

ix. Hargreaves, D. H. (2001). A Capital Theory of School Effectiveness and Improvement. British $\quad$ Educational Research Journal, 27 (4), 490-498.

x. Harwell, M. R. (2012). Research Designs in Qualitative/ Quantitative/ Mixed Methods.University of Minnesota.

xi. Khuzwayo, Q. O. (2016). Exploring What Sustainable School-Community Partnership Entails: A Case Study of Four Rural Primary School in Ndwendwe. Unpublished thesis.

xii. Litchman, M. (2006). Qualitative research ineducation. London: SAGE.

xiii. Mannathoko, M. C. (2013). Does Teaching Practice Effectively Prepare Student Teachers to Teach Creative and Performing Arts? The Case of Botswana. International Journal of Higher Education, Vol. 2 (2), pp. 115-121.

xiv. Senge, P. (2006). The Fifth Discipline: The Art and Practice of the learning Organization. London: Random House Business Books.

xv. Wambugu, P., Barmao, A, \& J., Ng'eno, (2013). Student Teachers' Perceptions of Teaching Practice in Egerton University, Kenya. Education Journal, Vol 2 (4), pp.169-175.

xvi. Wilson, S. M., Floden, R. E., \& Ferrini-Mundy, J. (2001). Teacher Preparation Research: Current Knowledge, Gaps and Recommendations. Center for the Study of Teaching and Policy, University of Washington. 